\title{
Identification of stage-specific and hormonally induced polypeptides in the uterine protein secretions of the mare during the oestrous cycle and pregnancy
}

\author{
M. T. Zavy, D. C. Sharp, F. W. Bazer, A. Fazleabas, F. Sessions and \\ R. M. Roberts
}

Department of Animal Science and Department of Biochemistry and Molecular Biology, University of Florida, Gainesville, Florida 32603, U.S.A.

\begin{abstract}
Summary. Uterine secretions were obtained on Days 4, 8, 12, 14, 16, 18 and 20 of the oestrous cycle and early pregnancy. Acid phosphatase activity was significantly affected by day of the cycle, reaching a maximum at Days 12-14 during the luteal phase and then declining to almost undetectable levels by Day 20. In pregnant animals, activity continued to increase beyond Day 14. Two-dimensional polyacrylamide gel electrophoresis showed that albumin was a major component. However, a number of unique proteins of non-serum origin appeared in mid-cycle but had disappeared by Day 20 . One of these was a basic protein indistinguishable in electrophoretic properties from the uterine acid phosphatase of the pig, uteroferrin, which is believed to be involved in iron transport from the uterine endometrial epithelium to the conceptus. These same polypeptides, including the putative uteroferrin, were also present in uterine flushings from pregnant animals until Day 20 , and in flushings from ovariectomized mares treated with progesterone but not in those given only oestradiol-17 $\beta$. Flushings from all ovariectomized animals contained a non-serum, acidic polypeptide (pI 5.3) of molecular weight 70000 . One basic polypeptide (molecular weight $\sim 17000$ ) appeared by Day 4 of the oestrous cycle and disappeared by Day 16 but was maintained during pregnancy until Day 20. It was absent, however, in flushings from a Day 45 pseudopregnant mare. Like the sow, therefore, the mare possesses a number of proteins associated with cyclic changes in steroid hormones during the oestrous cycle and early pregnancy.
\end{abstract}

\section{Introduction}

Secretions of the maternal genital tract have been proposed as having important roles in the reproductive process, including sperm capacitation, fertilization, production of luteolytic agents, pregnancy maintenance and nutritional support of the conceptus (see Bazer, Roberts \& Sharp, 1978a). Animals with a non-invasive trophoblast, and which have a diffuse, epitheliochorial placentation, rely upon uterine secretions for development of the conceptus to an extent that might be expected to be more complete, and of longer term, than do those animals in which there is more extensive erosion of the uterine epithelium and the placenta comes into close proximity to the maternal blood supply. In the pig, for example, uterine secretions are produced in copious amounts both during pregnancy (Basha, Bazer \& Roberts, 1980a) and under the influence of progesterone (Schlosnagle, Bazer, Tsibris \& Roberts, 1974; Basha, Bazer, Geisert \& Roberts, 1980b). These proteins undoubtedly have a variety of functions (Bazer et al., 1978a; Bazer, 
Roberts \& Thatcher, 1978b). However, among the most important is transport of waterinsoluble nutrients such as minerals (Roberts \& Bazer, 1980) or fat-soluble vitamins (Adams, Bazer \& Roberts, 1981). Indeed, these secretions have been likened to a complex embryo culture medium (Bazer et al., 1978a). One protein which is particularly characteristic of pig uterine secretions is the purple, iron-containing, glycoprotein known as uteroferrin (see Roberts \& Bazer, 1980). Although uteroferrin has acid phosphatase activity, its main role is considered to be in iron transport from mother to conceptus. Since both the horse and the pig have the same type of diffuse, epitheliochorial placentation (Hafez \& Jainudeen, 1974), it would not be unexpected that both species possess similar maternal-embryonic transfer systems for support of the conceptus. Zavy, Bazer, Sharp \& Wilcox (1979) have reported that the uterine secretions of mares under the influence of progesterone were purple in colour and contained a protein that showed partial cross-reactivity with antibodies raised against porcine uteroferrin. We have now studied the proteins that appear in the uterine secretions of Pony mares during the oestrous cycle and pregnancy and after steroid hormone injection, (a) to compare the secretory activity with that in sows, (b) to identify which proteins are steroid induced, and (c) to define the protein environment of the conceptus in early pregnancy.

\section{Materials and Methods}

Materials. Sources of chemicals for electrophoresis have been described elsewhere (Basha et al., 1980a).

\section{Preparation of animals and collection of uterine secretions}

Cyclic and pregnant mares. The 35 cyclic Pony mares were randomly assigned to 7 treatment groups. The breeding history of these mares was not known. The mares were teased daily by a vigorous stallion in order to detect oestrus. Ovulations (Day 0 ) were detected by daily rectal palpation of the ovaries in which developing follicles were $\geq 25 \mathrm{~mm}$ in diameter. Uterine flushings were collected on Days 4, 8, 12,14,16,18 and 20 after ovulation. Mares were allowed one complete oestrous cycle as a recovery period and were mated at the next oestrus to a fertile stallion. They were then ovario-hysterectomized on the same treatment day to which they had been previously assigned in the non-pregnant phase of this study. Using this design, flushings were collected from each mare on equivalent days of the oestrous cycle and pregnancy, and each animal therefore served as its own control.

Uterine flushings were collected from anaesthetized mares by a modification of the non-surgical, transcervical procedure described by Zavy, Bazer \& Sharp (1978). Before the collection, jugular blood samples were taken. Mares were then tranquillized with acepromazine, anaesthetized with thiopentone sodium (5\% solution, i.v.), and anaesthesia was maintained with halothane in oxygen. Mares were then placed in dorsal recumbency in a padded cart, the rear of which was raised to an angle of $30^{\circ}$ with the floor. Sterile $0.33 \mathrm{M}-\mathrm{NaCl}(60 \mathrm{ml})$ was introduced into the uterus via a modified Foley catheter. After mixing the uterine luminal contents for 5 min by repeated back-flushings into the syringe, the flushing was withdrawn and placed in sterile vials, cooled, measured for volume and frozen until laboratory analysis.

For collection of uterine flushings from pregnant animals, mares were prepared as previously described and then the ovaries and uterus were removed through a mid-ventral incision. The excised uterus was clamped and chilled on ice for $10 \mathrm{~min}$. A small incision was then made in the isthmic portion of the oviduct near the uterotubal junction through which $60 \mathrm{ml}$ sterile saline were infused via a polyvinyl catheter passing into the uterine lumen. After a mixing period of 5 min, a section of the uterine horn proximal to the uterotubal junction was excised in order to recover the blastocysts with their membranes intact. Uterine flushings were decanted into sterile 
culture dishes where blastocysts were separated from the flushing. This technique was successful for harvesting Day 8, 12, 14 and 16 blastocysts; however, because of the fragility of the membranes on Days 18 and 20 it was impossible to collect intact embryos and the uterine flushings were contaminated with some yolk-sac fluid. Flushings were processed as described by Murray, Bazer, Wallace \& Warnick (1972).

Hormone administration to ovariectomized animals. Twenty (20) ovariectomized mares were randomly assigned to four treatment groups: control 21 days; $10 \mathrm{mg}$ oestradiol-17 $\beta /$ day for 2 days; $150 \mathrm{mg}$ progesterone/day for 21 days or $10 \mathrm{mg}$ oestradiol-17 $\beta /$ day for 7 days followed by $150 \mathrm{mg}$ progesterone/day for 14 days. Hormone administration was begun by replicates with 2 days intervening between each replicate to allow sufficient time for surgery and sample harvesting. On Day 21 of treatment, mares were hysterectomized and uterine flushings were obtained as described above.

Pseudopregnant mare. A mare which was determined to be pregnant by palpation at Day 35 was found to be non-pregnant at Day 45 although corpora lutea were still present. Uterine flushings were collected at Day 45 as described above.

\section{Acid phosphatase activity protein determination}

The assay for acid phosphatase activity using $p$-nitrophenylphosphate as substrate has been described elsewhere (Schlosnagle, Sander, Bazer \& Roberts, 1976; Basha, Bazer \& Roberts, 1979). One unit of activity is defined as the capacity to release $1 \mu \mathrm{mol}$ nitrophenol $/ \mathrm{min}$ at $30^{\circ} \mathrm{C}$ in $0.1 \mathrm{M}$-acetate buffer, $\mathrm{pH} \mathrm{4.9}$. Protein was measured colorimetrically by the procedure of Lowry, Rosebrough, Farr \& Randall (1951).

\section{Statistical analysis}

Values for acid phosphatase and protein content of the uterine secretions from pregnant and non-pregnant mares were analysed by least squares regression analysis (Harvey, 1976) to evaluate the effects of day and status (pregnant versus non-pregnant) and to detect day-by-status interaction.

\section{Preparation of the samples for electrophoresis}

A dialysed sample of uterine secretions $(5 \mathrm{ml})$ was freeze-dried and the dried material was dissolved in $1 \mathrm{ml} 5 \mathrm{~mm}-\mathrm{K}_{2} \mathrm{CO}_{3}$ containing $9.3 \mathrm{M}$-urea, $2 \%(\mathrm{v} / \mathrm{v})$ Nonidet P-40 and $0.5 \%(\mathrm{w} / \mathrm{v}$ ) dithiothreitol and used for two-dimensional polyacrylamide gel electrophoresis (PAGE) (Horst, Basha, Baumbach, Mansfield \& Roberts, 1980).

\section{Two-dimensional polyacrylamide gel electrophoresis}

This analysis was performed according to a modification of the method of O'Farrell (1975) as described by Horst et al. (1980).

Isoelectric focussing $(I E F)$. The acidic proteins (i.e. $\mathrm{pI}<8.0$ ) were analysed by isoelectric focussing in the first dimension in $4 \%(\mathrm{w} / \mathrm{v})$ acrylamide gels containing $N, N^{\prime}-$ diallyltartardiamide (as a cross-linker), 9.3 M-urea, 2\% (v/v) Nonidet P-40 and 2\% (v/v) ampholines $(3 \cdot 5-10,5-7$ and $9-11,50: 35: 15$ by vol. respectively). The gels were then equilibrated for $10 \mathrm{~min}$ in $0.065 \mathrm{M}$-Tris- $\mathrm{HCl}$ buffer $(\mathrm{pH} 6.9)$ containing $1 \%(\mathrm{w} / \mathrm{v})$ SDS and $1 \%$ ( $v / v)$ 2-mercaptoethanol and subjected to electrophoresis in the second dimension in $10 \%$ acrylamide slab gels.

Non-equilibrium pH gradient electrophoresis (NEPHGE). The basic proteins were separated in the first dimension in $4 \%(\mathrm{w} / \mathrm{v})$ acrylamide gels prepared as described previously (Basha et al., 
1980a). The method is based on that of O'Farrell, Goodman \& O'Farrell (1977). The ampholines used in this gel system were $9-11,8-9.5$ and $6-8$ (70:20:10 by vol., respectively). The protein migration was towards the cathode and the duration of electrofocussing was $3.5 \mathrm{~h}$. At the end of the run, gels were equilibrated for $10 \mathrm{~min}$ as described above and subjected to SDS-polyacrylamide slab gel electrophoresis in $10 \%(\mathrm{w} / \mathrm{v})$ acrylamide gels. The final position of polypeptides in the first dimension during this analysis is influenced by the volume of the sample applied to the gel and this is the reason for some inconsistencies in polypeptide position between experiments.

Second dimension electrophoresis. SDS-gel electrophoresis was performed in $10 \%$ polyacrylamide gels (Basha et al., 1980a). After electrofocussing the equilibrated gels were overlayed on the $10 \%(\mathrm{w} / \mathrm{v})$ acrylamide slabs and electrophoresis was performed towards the anode. The slabs were fixed and stained with Coomassie blue R-250.

\section{Results}

Total protein in uterine flushings. Total recoverable protein from uterine flushings of non-pregnant and pregnant mares was not different (Text-fig. 1a) although a day-by-day status interaction approached significance $(P<0 \cdot 10)$. Additionally, there were no significant day effects for non-pregnant or pregnant mares (Text-fig. 1a).

(a)

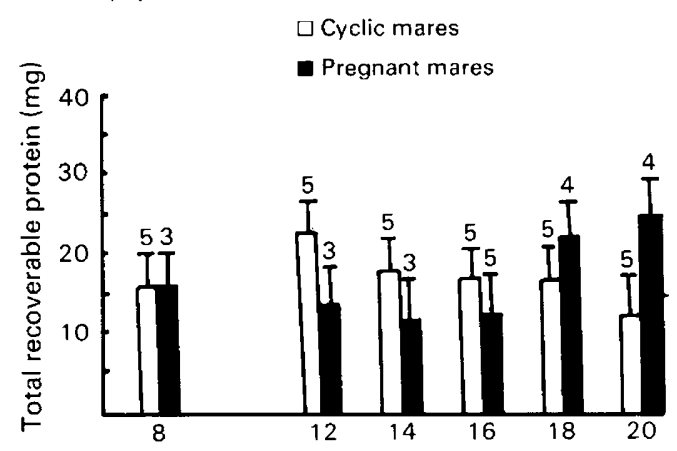

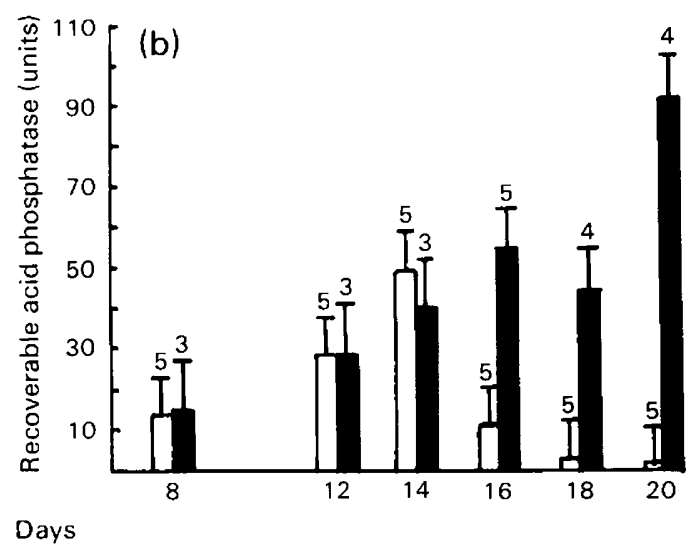

Days

Text-fig. 1. Total recoverable protein (a) and total acid phosphatase activity (b) in mare uterine flushings. Numbers above bars indicate the number of animals on each day; lines above bars represent standard errors of the least squares means. In (b) the activity unit is $\mu \mathrm{mol}$ $p$-nitrophenylphosphate hydrolysed/min.

Total protein in non-pregnant mares peaked on Day 12 of the oestrous cycle. In pregnant animals there was a decrease from Days 8 to 14 and then a continuous rise to Day 20.

Acid phosphatase activity. Acid phosphatase activity was significantly different on both a total $(P<0.001)$ and specific activity $(P<0.001)$ basis between non-pregnant and pregnant mares (Text-fig. 1b). A highly significant day-by-status interaction was found for total acid phosphatase activity $(P<0.001)$ and acid phosphatase specific activity $(P<0.001)$. Phosphatase activity (both total and specific) was also significantly affected by day of the oestrous cycle $(P<0.001)$ and day of pregnancy $(P<0.03)$.

In non-pregnant mares total acid phosphatase activity peaked on Day 14 and then declined rapidly. By contrast, in the pregnant animal there was a continued increase beyond Day 14. At Day 18 the amount of activity decreased slightly, but there was an apparent recovery by Day 20. In the non-pregnant animal acid phosphatase activity was less than one-fiftieth that of the pregnant animal at Day 20. 
Two-dimensional electrophoresis of secreted proteins

Plate 1, Figs 1 and 2, show the Coomassie blue-stained gels obtained after two-dimensional PAGE of the more acidic proteins in uterine secretions from mares at different days of the oestrous cycle and early pregnancy. Plate 2, Figs 3 and 4, show the separation of the basic proteins after NEPHGE in the first dimension. These results represent pooled samples obtained from at least 3 animals at each day of the cycle or pregnancy. Composite diagrams of the polypeptide maps are provided in Text-figs 2 and 3 . The gels have been divided arbitrarily into an alphabetical series of sectors and polypeptides of interest within any sector have been given a number. For example, protein spot $\mathrm{C}_{1}$ is serum albumin. It appears on all days of the oestrous cycle and pregnancy; other serum proteins, such as light and heavy chains of immunoglobins, are also evident.

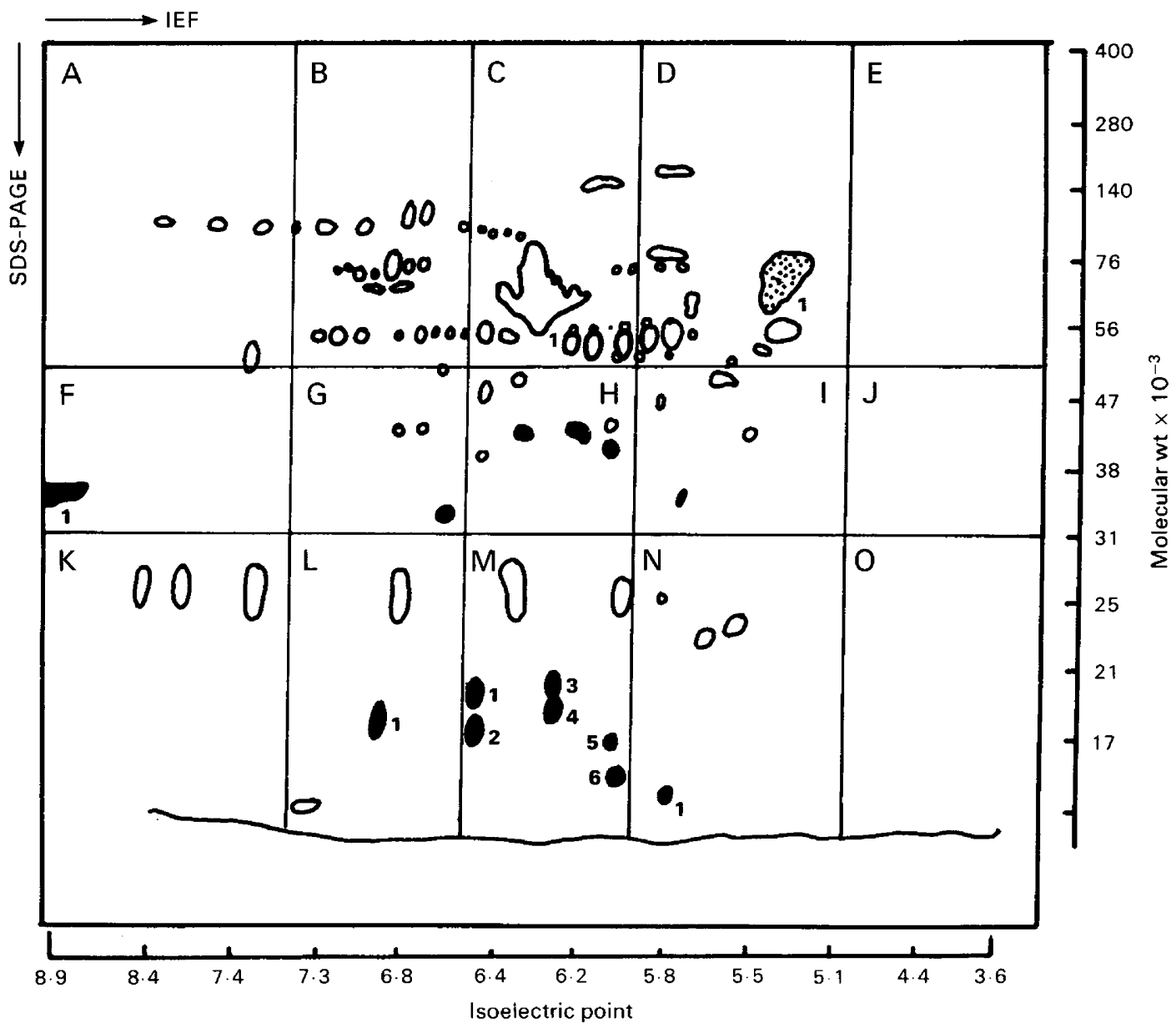

Text-fig. 2. Diagram showing positions on two-dimensional polyacrylamide gels of the more acidic group of polypeptides found in mare uterine flushings. The $\mathrm{pH}$ gradient in the IEF gel is drawn on the horizontal axis, and a molecular weight scale is shown for the second dimension on the right. Major polypeptides induced by progesterone are shown in black; the single polypeptide appearing uniquely after oestradiol-17 $\beta$ administration $\left(D_{1}\right)$ is stippled. Other polypeptides (unfilled areas) are probably serum-derived. 


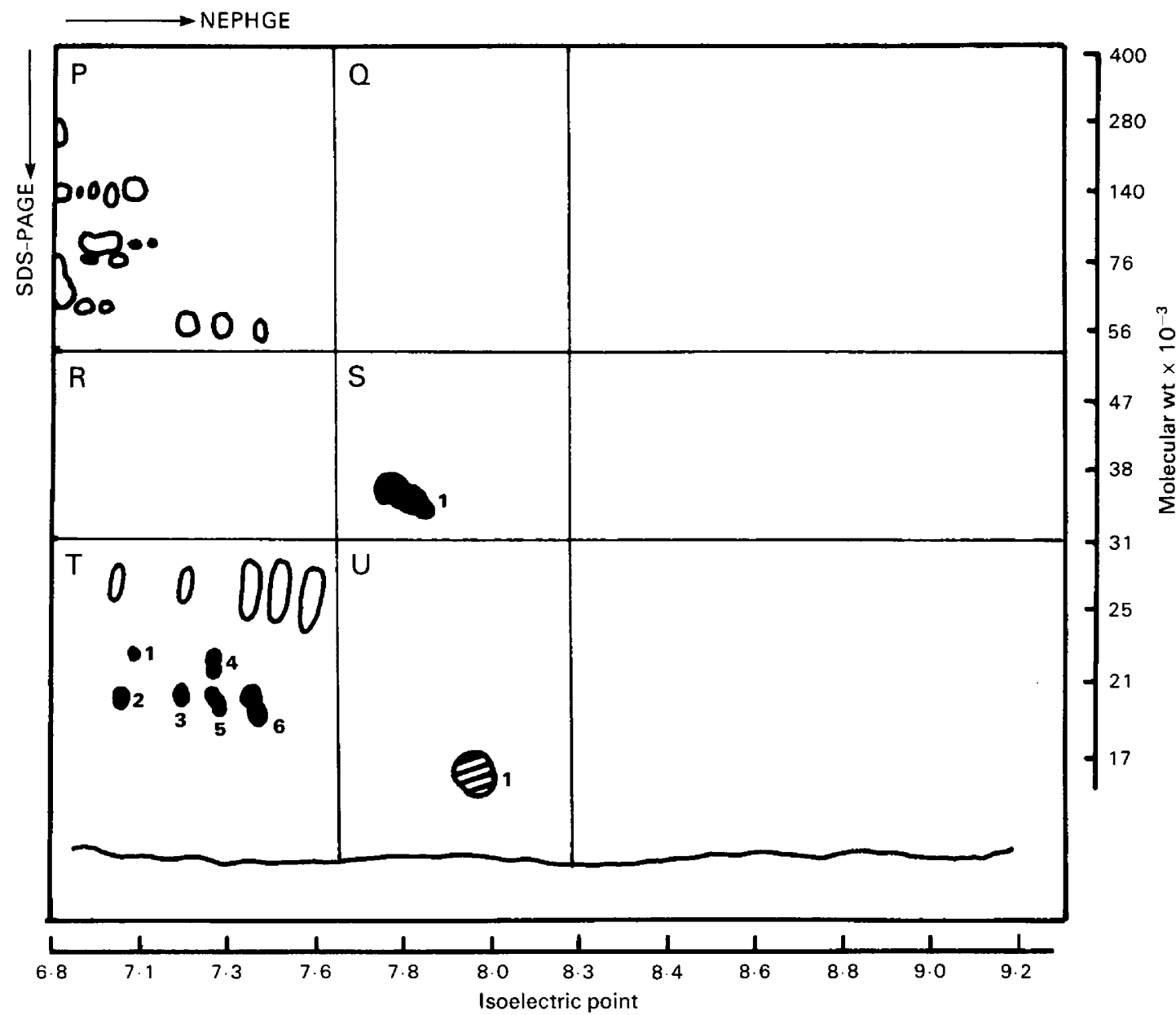

Text-fig. 3. Diagram showing the positions on NEPHGE gels of the major basic polypeptides found in mare uterine flushings. The $\mathrm{pH}$ gradient existing at the time electrophoresis was terminated in the first dimension is shown by the horizontal scale. A molecular weight scale for the second dimension is shown on the right. Major polypeptides induced by progesterone are shown in black. A single polypeptide $\left(U_{1}\right)$ which is not induced by progesterone or oestradiol-17 $\beta$ but is cyclic in its appearance is indicated by cross-hatching. Other polypeptides (unfilled areas) are probably serum-derived.

\section{PLATE 1}

Figs 1 and 2. Two-dimensional electrophoresis (2D-PAGE) of the uterine flushings from pregnant (Fig. 1) and non-pregnant (Fig. 2) mares at various days after oestrus. Approximately $100 \mu \mathrm{g}$ protein were loaded onto each gel. The grouped gels (Days 4-20) show only a part of each gel between $\mathrm{pH} 7.5$ and 5.8 of the $\mathrm{pH}$ gradient. The single gels are entire examples. Some of the polypeptides referred to in the text and in Text-fig. 2 are marked in the single gel of Fig. 1.

\section{PLATE 2}

Figs 3 and 4. Two-dimensional electrophoresis (NEPHGE) of the basic proteins in uterine flushings from pregnant (Fig. 3) and non-pregnant (Fig. 4) mares at various days after oestrus. Approximately $100 \mu \mathrm{g}$ protein were loaded onto each gel. The grouped gels (Days 4-20) show only the left half of each gel (up to $\mathrm{pH} 8.0$ in the electrophoresis dimension). The single gels are entire examples. Some of the polypeptides referred to in the text and in Text-fig. 3 are marked in the single gel of Fig. 3 . 
PLATE 1

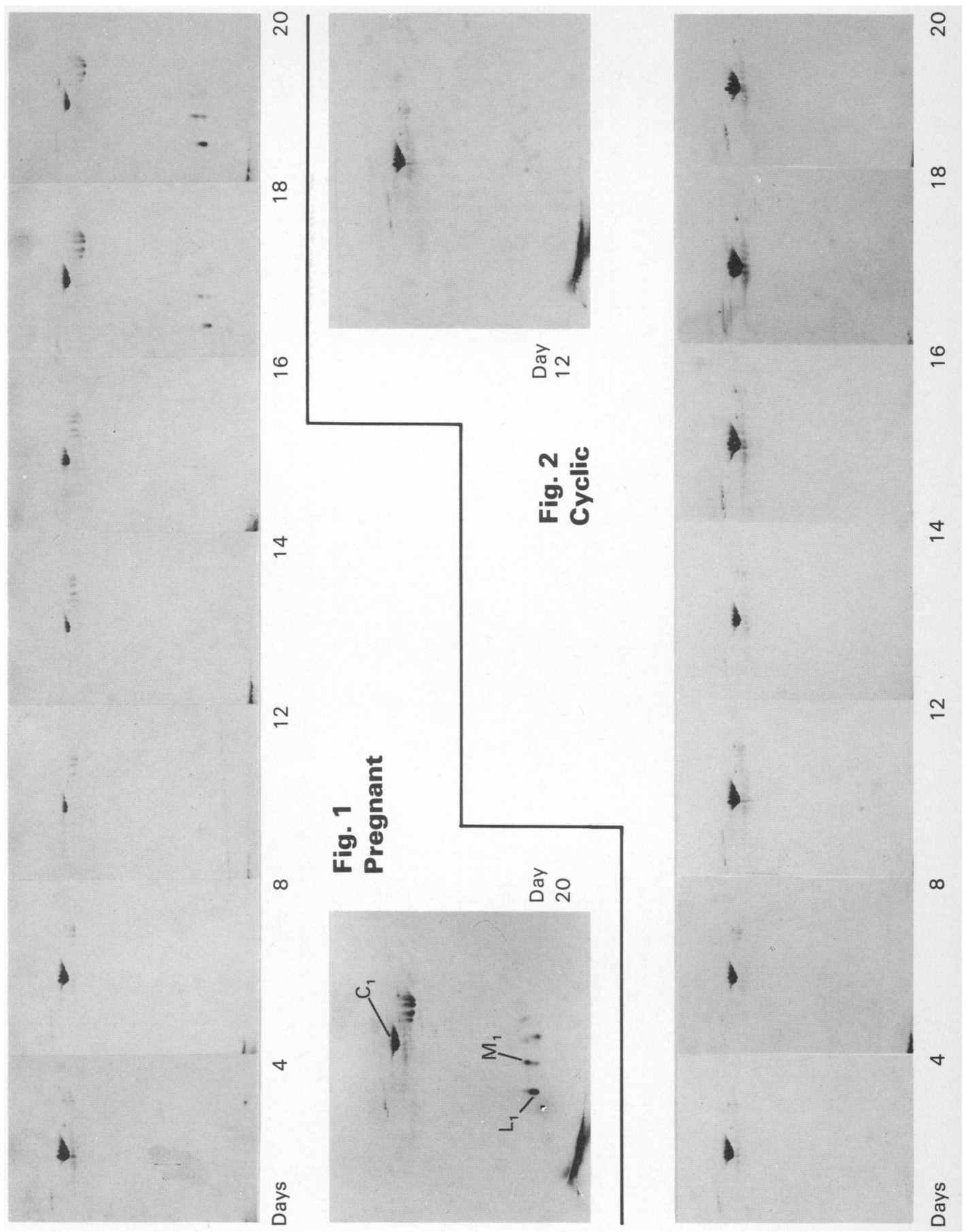

(Facing p. 204) 
PLATE 2

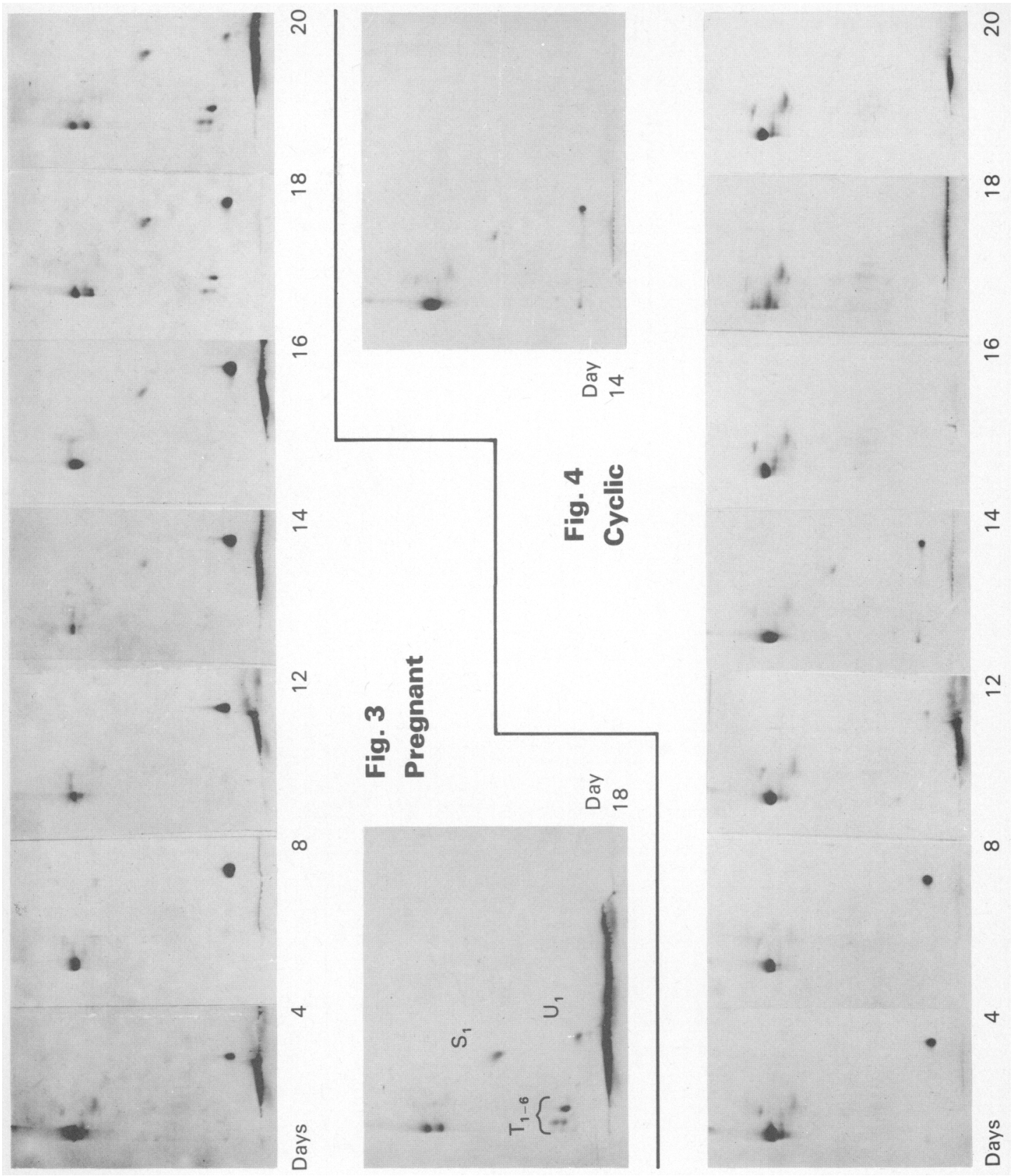


Plate 3
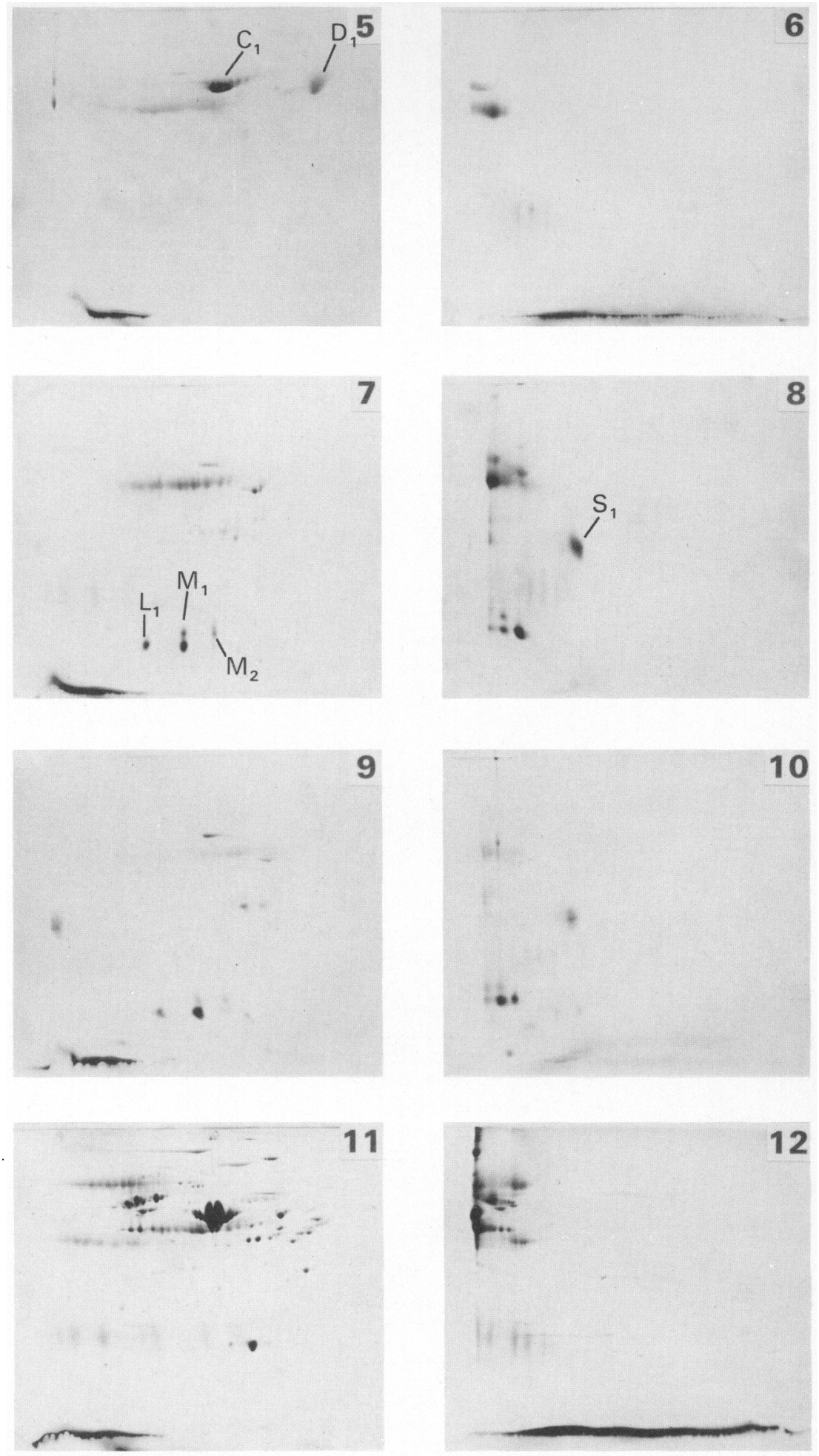
Several acidic polypeptides, however, did not correspond with any of those found in serum (see Pl. 3, Figs 11 and 12). Moreover, they appeared only transiently during the oestrous cycle. These included the low molecular weight polypeptides $L_{1}, N_{1}, M_{1-6}$ and a few minor components in sector $\mathrm{H}$. These have been filled in completely in Text-figs 3(a) and 3(b). The polypeptides were clearly evident only on Day 12 and to some extent on Days 14, 16 and 18 of the oestrous cycle, after which they disappeared. During pregnancy, however, the polypeptides were maintained and continued to increase in amount. They were also found at Day 45 in the pseudopregnant mare (Pl. 3, Fig. 9). These same proteins were also detectable in the uterine secretions of ovariectomized mares treated with progesterone (Pl. 3, Fig. 7), or oestrogen followed by progesterone but not oestradiol-17 $\beta$ alone (P1. 3, Fig. 5).

Of the basic proteins, several polypeptides appeared only during the luteal phase of the cycle around Day 12 (Pl. 2, Fig. 4; Text-fig. 3), or in mares treated with progesterone (Pl. 3, Fig. 8). These included $T_{1-6}$ and $S_{1}$. The latter has an electrophoretic mobility identical to the purple porcine glycoprotein uteroferrin. The $T_{1-6}$ and $S_{1}$ spots also appeared in pregnant animals at around Day 12, but, rather than disappearing as in the oestrous cycle by Day 16, they were maintained and continued to increase in amount until Day 20 of pregnancy. They were also found in flushings from the pseudopregnant mare (Pl. 3, Fig. 10).

In ovariectomized animals treated with oestradiol, two major polypeptides were detected by two-dimensional electrophoresis (Pl. 3, Fig. 5); one was albumin, while the other, $\mathrm{D}_{1}$, appeared to be oestrogen-induced. Polypeptide $D_{1}$ was evident as a diffuse spot of molecular weight 70000 and $\mathrm{pI} 5 \cdot 3$. It could sometimes be detected as a very faint spot in the secretions from mares in the luteal phase or pregnancy.

The basic polypeptide $U_{1}$ was clearly not of serum origin but appeared early in the oestrous cycle. It was detectable on Day 3, was maintained until Day 14 and then disappeared (Pl. 2, Fig. 4). In pregnant animals, however, it was still present at Day 20 , but in smaller amounts than at Days 12 and 14. It was not induced by progesterone or oestradiol-17 ( Pl. 3, Figs 6 and 8 ) and was not found in flushings from the Day- 45 pseudopregnant mare (Pl. 3, Fig. 10), or in serum (Pl. 3, Fig. 12).

\section{Discussion}

The amounts of protein recovered from pregnant and non-pregnant Pony mares are similar to those reported for early pregnant cows (Roberts \& Parker, 1974). They are considerably less than amounts isolated from the uterus of pigs at comparable stages of the oestrous cycle and pregnancy (Murray et al., 1972). However, in part, this might be a reflection of the large uterine surface area of the pig compared with that of the mare at these stages.

\section{PLATE 3}

Two-dimensional electrophoresis of polypeptides present in uterine flushings of steroid-treated mares, uterine flushings of a pseudopregnant mare and in serum.

Fig. 5. PAGE of uterine flushings from mares treated with oestradiol-17 $\beta$.

Fig. 6. NEPHGE of uterine flushings from mares treated with oestradiol-17 $\beta$.

Fig. 7. PAGE of uterine flushings from mares treated with progesterone.

Fig. 8. NEPHGE of uterine flushings from mares treated with progesterone.

Fig. 9. PAGE of flushings from the pseudopregnant mare ( $100 \mu \mathrm{g}$ protein analysed).

Fig. 10. NEPHGE of flushings from the pseudopregnant mare ( $100 \mu \mathrm{g}$ protein analysed).

Fig. 11. PAGE of serum ( $250 \mu \mathrm{g}$ protein) from a Day- 20 mare.

Fig. 12. NEPHGE of serum ( $250 \mu \mathrm{g}$ protein) from a Day- 20 mare. 
In the pig, acid phosphatase activity of uterine secretions is due almost entirely to the presence of the purple glycoprotein uteroferrin and there is, therefore, a direct correlation between phosphatase activity of the secretions and their uteroferrin content (Schlosnagle et al., 1974; Basha et al., 1980b). In the mare the amount of total protein is much less than in the pig and the content of uteroferrin has not been accurately measured. Nevertheless, it is tempting to suggest that the acid phosphatase activity in mare uterine secretions is due to a uteroferrin-like protein for four reasons. (1) A small amount of a purple protein with the electrophoretic properties of uteroferrin has been purified from mare uterine secretion and shown to have acid phosphatase activity (K. McDowell, D. C. Sharp, A. Fazleabas \& R. M. Roberts, unpublished). (2) Horse uterine phosphatase has an elution position identical to that of porcine uteroferrin during Sephadex G-200 chromatography (Zavy et al., 1979). (3) Mare uterine secretions cross-react immunologically with antibody to porcine uteroferrin (Zavy et al., 1979). (4) The polypeptide in mare secretions, which has an electrophoretic mobility identical to that of uteroferrin in our two-dimensional system, peaks at Days 12-14 in the non-pregnant animal but continues to be produced in the pregnant animal to Day 20. It is not detectable in mares early in pregnancy or before Day 12 of the cycle. This correlates well with the trends in acid phosphatase activity shown in Text-fig. 2.

In the pig, uteroferrin production is regulated by progesterone. Clearly this appears also to be true in the mare, because protein $S_{1}$ (putative uteroferrin) is detectable only in ovariectomized animals given progesterone and not in those given oestradiol-17\%. In addition, its appearance in the oestrous cycle is limited to the phase when progesterone levels are elevated (Sharp \& Black, 1973; Ganjam, Kenney \& Flickinger, 1975; Zavy, 1979).

Other than for the presence of a uteroferrin-like protein, the uterine secretions of the mare were not markedly similar in quality to those of the pig. There were, however, a number of polypeptides that appeared to be induced by progesterone. These included spots $L_{1}, M_{1-6}, N_{1}$ and those of the $T$ series. In fact, spots $L_{1}$ and $M_{1-6}$ are probably identical to the $T$ series polypeptides. The isoelectric points are about neutral so they would be expected to migrate into the NEPHGE gel as well as to reach their isoelectric point during standard isoelectric focussing. It should be emphasized that, during NEPHGE, polypeptides do not reach their isoelectric point, because their rate of migration in the first dimension is governed primarily by their charge and size. However, other than their electrophoretic properties we know very little about this group of proteins or what their function might be. One particularly interesting member of the family of secreted uterine proteins is $U_{1}$. This basic polypeptide appears early in the oestrous cycle and is found in pregnant and non-pregnant mares. However, while it is maintained during pregnancy, it disappears after Day 14 of the cycle in the non-pregnant animal. It cannot be induced by progesterone or oestrogen. Thus, although it is of uterine origin and shows cyclic changes in quantity, the hormonal basis for its appearance remains unknown. Its induction may require a combination of a gonadotrophin and a steroid.

We have also identified at least one component $\left(D_{1}\right)$ which can be induced by oestradiol-17 $\beta$. This polypeptide gives a diffuse spot upon staining with Coomassie blue, making its detection difficult. Oestrogen-induced proteins have not been detected in pig uterine secretions.

We therefore conclude that the uterus of the Pony mare, like that of the pig, secretes a characteristic set of proteins under the influence of progesterone. Other than for the presence of a uteroferrin-like protein in animals of both species the qualitative make-up of the two sets of secretions appears to be distinct. Nevertheless, it is clear that the uterine environment of the pregnant Pony mare includes a unique set of progesterone-induced proteins, whose function presumably relates to the maintenance of the conceptus.

This research was supported by NIH grants HD 08560 and HD 10436 to F.W.B. and R.M.R., and a grant from the Morris Animal Foundation to D.C.S. We thank Dr C. J. Wilcox for statistical help. Florida Agricultural Research Station Journal Series number 3036. 


\section{References}

Adams, K.L., Bazer, F.W. \& Roberts, R.M. (1981) Progesterone-induced secretion of a retinol-binding protein in the pig uterus. J. Reprod. Fert. 62, 39-47.

Basha, S.M.M., Bazer, F.W. \& Roberts, R.M. (1979) The secretion of a uterine specific, purple phosphatase by cultured explants of porcine endometrium. Dependency upon the state of pregnancy of the donor animal. Biol. Reprod. 20, 431-441.

Basha, S.M.M., Bazer, F.W. \& Roberts, R.M. (1980a) Effect of the conceptus on quantitative and qualitative aspects of uterine secretion in pigs. J. Reprod. Fert. 60, 41-48.

Basha, S.M.M., Bazer, F.W., Geisert, R.D. \& Roberts, R.M. (1980b) Progesterone-induced uterine secretions in pigs. Recovery from pseudopregnant and unilaterally pregnant gilts. J. Anim. Sci. 50, 113-123.

Bazer, F.W., Roberts, R.M. \& Sharp, D.C. (1978a) Collection and analysis of female genital tract secretions. In Methods in Mammalian Reproduction, pp. 503-538. Ed. J. C. Daniels. Academic Press, New York.

Bazer, F.W., Roberts, R.M. \& Thatcher, W.W. (1978b) Actions of hormones on the uterus and effect on conceptus development. J. Anim. Sci. 49, Suppl. 2, $35-45$.

Ganjam, V.K., Kenney, R.M. \& Flickinger, G. (1975) Plasma progestagens in cyclic, pregnant and postpartum mares. J. Reprod. Fert., Suppl. 23, 441-447.

Hafez, E.S.E. \& Jainudeen, M.K. (1974) Gestation, prenatal physiology and parturition. In Reproduction in Farm Animals, 3rd edn, pp. 172-178. Ed. E. S. E. Hafez. Lea and Fabiger, Philadelphia.

Harvey, W.R. (1976) Least squares analysis of data with unequal subclass frequencies. USDA, ARS 20.

Horst, M.N., Basha, S.M.M., Baumbach, G., Mansfield, E.H. \& Roberts, R.M. (1980) Alkaline urea solubilization, two dimensional electrophoresis and lectin staining of mammalian plasma membrane and seed proteins. Analyt. Biochem. 102, 399-408.

Lowry, O.H., Rosebrough, N.J., Farr, A.L. \& Randall, R.J. (1951) Protein measurement with the Folin phenol reagent. J. biol. Chem. 193, 265-275.
Murray, F.A., Bazer, F.W., Wallace, H.D. \& Warnick, A.C. (1972) Quantitative and qualitative variation in the secretion of protein by the porcine uterus during the estrous cycle. Biol. Reprod. 7, 314-320.

O'Farrell, P.H. (1975) High resolution, two-dimensional electrophoresis of proteins. J. biol. Chem. $\mathbf{2 5 0}$, 4007-4021.

O'Farrell, P.Z., Goodman, H.M. \& O'Farrell, P.H. (1977) High resolution two dimensional electrophoresis of basic as well as acidic proteins. Cell 12 , 1133-1142.

Roberts, G.P. \& Parker, J.M. (1974) Macromolecular components of the luminal fluid from the bovine uterus. J. Reprod. Fert. 40, 291-303.

Roberts, R.M. \& Bazer, F.W. (1980) The properties, function and control of synthesis of uteroferrin, the purple protein of the pig uterus. In Steroid Induced Proteins, pp. 133-149. Ed. M. Beato. Elsevier-North Holland, Amsterdam.

Schlosnagle, D.C., Bazer, F.W., Tsibris, J.C.M. \& Roberts, R.M. (1974) An iron-containing phosphatase induced by progesterone in the uterine fluids of pigs. J. biol. Chem. 249, 7574-7579.

Schlosnagle, D.C., Sander, E.G., Bazer, F.W. \& Roberts, R.M. (1976) Requirements of an essential thiol group and ferric ion for the activity of the progesteroneinduced porcine uterine phosphatase. J. biol. Chem. $251,4680-4685$.

Sharp, D.C. \& Black, D.L. (1973) Changes in peripheral plasma progesterone throughout the oestrous cycle of the pony mare. J. Reprod. Fert. 33, 535-538.

Zavy, M.T. (1979) A comparison of the nonpregnant and pregnant uterine luminal environments in the porcine and equine. Ph.D. thesis, University of Florida.

Zavy, M.T., Bazer, F.W. \& Sharp, D.C. (1978) A nonsurgical technique for the collection of uterine fluid from the mare. J. Anim. Sci. 47, 672-676.

Zavy, M.T., Bazer, F.W., Sharp, D.C. \& Wilcox, C.J. (1979) Uterine luminal proteins in the cycling mare. Biol. Reprod. 20, 689-698.

Received 23 April 1981 